Hilson, G. R. F. \& Elek, S. D. (1954). J. gen. Microbiol. 11, 247-249

\title{
A Nylon Tissue Grinder
}

\author{
By G. R. F. HILSON AND S. D. ELEK \\ The Department of Bacteriology, St George's Hospital Medical \\ School, London, S.W. 1
}

SUMMARY: A tissue grinder is described, consisting of a nylon pestle mounted on a stainless steel shaft and revolving within a Pyrex tube; a screw is cut in the pestle to increase its efficiency. The whole device is sealed with a Subaseal bung and may be sterilized by autoclaving. Optimum grinding with minimum heating is produced by rotating the pestle at 500 r.p.m. with a small electric motor.

Tissue homogenizers are frequently required for biological and chemical studies. The usual type consists of a glass pestle fitting closely into a large glass test tube. In 1922 Hagan devised a simple form of grinder of this kind from two test tubes; this design was modified by TenBroeck (1931). Glaser \& Coria (1935) elongated the pestle so that it could be attached to a motor, and Potter \& Elvehjem (1936) fused glass beads on to the pestle, in order to tear up the tissue more effectively. This device is rotated by a cone-drive stirring motor at a speed of 80-90 r.p.m. (Parker, 1950) and is protected from contamination by a canopy of fibreglass cloth. Potter (1948) described an improved design and suggested a speed of about 1000 r.p.m. as optimal. Pyrex tubes with motordriven pestles are, however, unsatisfactory in practice since the grinding surfaces wear away after being used 10-20 times, and the clearance is greatly increased. This leads to inefficient grinding, and large particles may be left; serious errors in enzyme determinations may arise in this way. For this reason Brendler (1951) suggested the use of pestles made of Lucite as it has better wearing qualities and powdered glass does not appear in the homogenates. Pestles made of stainless steel and Teflon (Pierce, Dubos \& Schaefer, 1953) have also been used. The latter material is a synthetic tetrafluoroethylene resin resistant to organic solvents, acids and alkalies and to autoclaving. Nylon has similar qualities and was therefore used in the grinder described below. Mechanical rotation is far more efficient and convenient than grinding by hand, but the risk of overheating is present and must be guarded against. Ideally the design should combine high grinding efficiency with minimal heat production.

The type of grinder we used is shown in Pl. 1, figs. 1 and 2; it consists of a stout Pyrex test tube about $18 \mathrm{~cm}$. long with an internal diameter of about $1 \mathrm{~cm}$. Its upper part is expanded to receive a rubber 'Subaseal' bung with a central sleeve; in the illustration the sleeve is shown very much wider than the central spindle. For materials which might give rise to a dangerous aerosol, a bung should be fitted whose central sleeve is an easy fit on the spindle, tight enough to prevent the escape of fine particles of spray, but allowing rotation of the spindle. The spindle is a flexible stainless steel rod of about $3 \mathrm{~mm}$. 
diameter. This is set into the pestle, being locked in position by a small transverse screw. The pestle is turned on a lathe from a length of nylon rod 7.5 by $1 \mathrm{~cm}$. to fit the Pyrex tube with a tolerance of about $0.1 \mathrm{~mm}$. An Archimedean screw is cut into the lower third of the pestle, starting deeply and with a coarse pitch at the tip, and continuing upwards with diminution of both depth and pitch. The screw is cut in a direction opposite to the direction of rotation. The upper two-thirds of the pestle are smooth. All parts of the grinder may be autoclaved.

The grinder is used by placing in the tube about $5 \mathrm{ml}$. of the coarse suspension to be ground; the spindle of the pestle is attached to the chuck of a motor by a flexible drive. After starting the motor the pestle is firmly pressed into the suspension, the particles of suspension being forced up the channel of the screw. The particles are minced as the groove in which they travel becomes more and more shallow and they are finally ground between the smooth surface of the upper end of the pestle and the glass wall. The flexibility of the spindle produces an eccentric rotation of the pestle, resulting in a grinding force which is shearing in nature. When the pestle has reached the bottom, it is lifted up, with or without stopping the motor, and the process repeated.

Preliminary tests of the grinder, using bacterial suspensions, showed markedly decreased viable counts after grinding. It was not clear whether this was due to frictional heat or to pressure effects : high pressure is known to be lethal to bacteria, $5000 \mathrm{~kg} . / \mathrm{cm} .^{2}$ being said to be sufficient to sterilize cultures of Salmonella paratyphi-C (Vignais, Barbu, Macheboeuf \& Bassett, 1952). We did not consider it practicable to investigate pressure conditions within the grinder, but were able to make estimations of temperature rise at the frictional surfaces. A copper-constantan thermocouple of fine wire was wound round the smooth part of the pestle, and while the latter was held stationary, the glass tube was rotated at varying speeds. This allowed continuous readings to be taken. Five ml. portions of a coarse suspension $(c .50 \%, v / v)$ of rabbit liver were ground for up to $5 \mathrm{~min}$. At high speeds much frictional heat was generated and such speeds are unsuitable. At 500 r.p.m. the temperature rise at the surface of a smooth pestle was not more than $3.5^{\circ}$ in $5 \mathrm{~min}$. and was less with the screw-cut pestles. The grinding efficiency of plain and screw-cut pestles at 500 r.p.m. was compared by making haematocrit readings of the same material ground for the same periods of time. Judged in this way, the Archimedean screw cut pestle appeared to be more efficient.

\section{REFERENCES}

Brendier, H. (1951). A simple, inexpensive microhomogenizer. Science, 114, 61. Glaser, R. W. \& Coria, N. A. (1935). Culture and reactions of purified protozoa. Amer. J. Hyg. 21, 111.

Hagan, W. A. (1922). The value of heat-killed cultures for the prevention of the Brucella abortus inoculation disease of guinea-pigs. J. exp. Med. 36, 711.

Parker, R. C. (1950). Methods of Tissue Culture. London: Cassell and Co. Ltd.

Pierce, C. H., Dubos, R. J. \& Schaefer, W. B. (1953). Multiplication and survival of tubercle bacilli in the organs of mice. J. exp. Med. 97, 189. 
PotTer, V. R. (1948). In W. W. Umbreit, R. H. Burris \& J. F. Stauffer (eds.): Manometric Techniques and Related Methods for the study of Tissue Metabolism, p. 92. Minneapolis, U.S.A.: Burgess Publ.

Potter, V. R. \& Elvenjem, C. A. (1936). A modified method for the study of tissue oxidations. J. biol. Chem. 114, 495.

TenBroeck, C. (1931). A simple grinder for soft tissues. Science, 74, 98.

Vignais, P., Barbu, E., Macheboevf, M. \& Bassett, M. (1952). Pouvoirs antigène et vaccinant de bactéries tuées par pression. Bull. Soc. Chimie biol., Paris, 34, 43.

(Received 28 April 1954) 